\title{
Use of lonophores in Goat Feeding
}

\author{
M. G. Muro¹ , R. Arias ${ }^{1}$, M. S. Trigo¹, M. A. Eirin¹, A. C. Cattáneo², \\ K. Steffen ${ }^{2}$, C. A. Cordiviola ${ }^{1}$
}

${ }^{1}$ University Chair of Introduction to Animal Production. Faculty of agrarian and forestry sciences, National University of La Plata -UNLP

${ }^{2}$ Veterinary science faculty- UNLP

\begin{abstract}
The objective of this study was to evaluate the effect of monensin addition on the total dry matter intake, in goat diets, composed of $30 \%$ alfalfa hay and $70 \%$ corn. Four fistulated cross breed goats (Nubian x Creole), $39.77 \pm 1.07 \mathrm{~kg}$ live body weight $(\mathrm{BW})$, were used in experimental design. Two experiments were carried out: I) Determining total dry matter intake (TDMI), pasture dry matter intake (PDMI), total daily and hourly intake (TDHI) and total dry matter digestibility (TDMD); II) Determining ruminal $\mathrm{pH}$. Treatments consisted of an instance without monensin (D0), and another one with monensin (D1). In both cases, intake level was adjusted to $3 \%$ of BW. There were no significant effects $(\mathrm{p}<0.05)$ on TDMI, PDMI, TDHI, TDMD and BW. The registered TDHI during the 12 $\mathrm{h}$ after feed had an effect on time. The area below the curve, with a 5.8 and $6 \mathrm{pH}$ threshold, proved a significant linear drop-off $(\mathrm{p}<0.05)$ for D1. As regards the hours with $\mathrm{pH}$ value below $\mathrm{pH}$ threshold, there were no significant differences $(p>0.05)$ between treatments, only a tendency $(\mathrm{p}=0,074)$ to keep $\mathrm{pH}$ values below 5.8 for a greater number hours in D0. The average $\mathrm{pH}$ of the day showed a tendency to be higher $(\mathrm{p}=0,056)$ for D1. The lowest ruminal $\mathrm{pH}$ was observed between the 8 and $12 \mathrm{~h}$ after food intake, and with significant differences $(\mathrm{p}>0.05)$ between hours, but the treatment had no effects on the evolution of $\mathrm{pH}$ in time. Therefore, we can conclude that the addition of monensin in highly energetic diets for goats had a moderating effect in the ruminal $\mathrm{pH}$, and in the number of daily food concentrate meals. However, there was no register of acute acidosis with these diets.
\end{abstract}

Keywords: Monensin, Goats, Intake

\section{Introduction}

Ground cereal grains produce in sufficient saliva secretion to maintain $\mathrm{pH}$ values between 6 and 7 and low ruminal motile stimuli in all ruminant species (Gonçalves, 2001). Ramos (2005) and Milleo et al., (2006) claim that when starch consumption increases, the ruminal $\mathrm{pH}$ can get below 6 and fiber digestion and microbial development can decrease. Arias et al., 2013 proved that goat diets including energetic grains from $1 \%$ of $\mathrm{BW}$ produced a significant linear decrease of ruminal $\mathrm{pH}$ and rumen degradability of the forage. Another digestive problem, ketosis, also seen in dairy cows or sheep, may also be encountered in goats (Harwood, 2004). One potential way to help reduce the negative energy balance may be through the addition of ionophores. Ionophores act altering rumen microflora through ion transfer across cell membranes. The presence of ionophores (monensin, lasalocide, etc.) in goat diets is necessary to avoid excessive consumption, ruminal acidosis, and ketosis, as mentioned above (Pordomingo et al., 1999; Raun et al., 1976). The most commonly used ionophore is monensin, which acts on the ruminal bacteria that produces acetate and butyrate and increases the presence of microbes producing gluconeogenic precursor propionate (Bergen \& Bates, 1984; Church, 1988; Pordomingo et al., 1990; Santini \& Di Marco, 1983; Duff et al., 1990). One of the most important factors in the growth of ruminant bacteria population is $\mathrm{pH}$. Monensin has an indirect effect on ruminal $\mathrm{pH}$ : it inhibits the development of lactate producing Gram-positive bacteria (Dennis et al., 1981). It was observed that the use of monensin produces a decrease in daily intake and amount of food consumed in individual meals, and an increase in the number of meals per day, without modifying weight gain, which implied a better food conversion (Erickson et al., 2003; Bergen \& Bates, 1984). The use of monensin in wool sheep breeds showed no significant differences as regards intake reduction, and no improvements on digestibility of the diet consumed (Baran\&Žitñan 2002; Mouro et al., 2006; Mazza et al., 2001; Plata et al., 2004; Araújo et al., 2006). Rasool Sadjadian et al., (2013) evaluated the impact of monensin on metabolic parameters, dry matter intake and milk production in periparturient dairy goats. Monensin use caused a reduction of serum of $\beta$-Hydroxybutyrate concentration in the

This article is published under the terms of the Creative Commons Attribution License 4.0

Author(s) retain the copyright of this article. Publication rights with Alkhaer Publications.

Published at: http://www.ijsciences.com/pub/issue/2018-06/

DOI: 10.18483/ijSci.1706; Online ISSN: 2305-3925; Print ISSN: 2410-4477 
postpartum period. However, this improved energy metabolism did not result in a greater amount of milk production, or in improved dry matter intake. On the other hand, milk fat percentage significantly decreased in monensin fed goats, which is considered an undesirable quality for goat milk. Monensin use significantly decreased dry matter intake during the pre-partum period. However, Monensin is a promising tool for improving the energy status of dairy goats during a transition period. The objective of this study was to evaluate the effect of monensin addition to goat diets on the total dry matter intake and the ruminal $\mathrm{pH}$.

\section{MATERIALS AND METHODS}

This production was regulated and authorized by the Institutional Committee for the Care and Use of Laboratory Animals of the School of Veterinary Sciences of the National University of La Plata. Whose file number is 62-6-17 T.

The study was conducted in the goat's experimental unit of the School of Agricultural and Forestry Sciences of the National University of La Plata.

Experiment I: determining total dry matter intake (TDMI), pasture dry matter intake (PDMI), total daily and hourly intake (TDHI) and total dry matter digestibility (TDMD).

Four five year old, non-pregnant, non-lactating, cross breed goats (Nubian x Creole), $39.77 \pm 1.07 \mathrm{~kg}$ live weight $(\mathrm{BW})$, were used. They were fistulated with specific permanent cannulae for small ruminants in crossover design with two replicates and a 7-day washout period in between treatments. Goats were housed in individual compartments $(0.80 \mathrm{~m} \times 1.50 \mathrm{~m})$ that counted with feeders and automatic drinking devices. Each animal's weight was recorded at the beginning of each period. Ionophore monensin was added and the diets tested were composed of: $30 \%$ alfalfa hay plus $70 \%$ ground corn, without monensin (D0); and $30 \%$ alfalfa hay plus $70 \%$ ground corn, with monensin (D1).Table 1 shows diets chemical composition. The level of intake was adjusted to $3 \%$ of the BW, and an assimilation 21-day period was implemented prior to determinations. Ground corn was provided in an increasing manner (70 $\mathrm{g}$ per animal per day) until reaching the corresponding quantity at the beginning of the third week of the adaptation period. Alfalfa hay and ground corn samples were taken and heat dried for determination of dry matter. (AOAC, 1995). Individual intake of alfalfa hay and ground corn was calculated considering the difference between provided and rejected food, expressed in $\mathrm{kg}$ of DM. Alfalfa hay and ground corn intake was determined. For the latter, a repeated measure model was used in order to evaluate the time effect post feeding and the hour/treatment interaction.
TDMD was determined by a methodology consisting in providing food and collecting the total amount of stool by means of a collection bag and a harness (Moore et. al, 2002). Collection bags were emptied once a day and the total amount of stool was weighted. DM content and consumed TDMD were determined, with a $10 \%$ aliquot of the animal's stools, by the porcentual difference of total portion consumed and the excreted amount in relation to the consumed one, expressed in percentage.

Experiment II: ruminal $p H$ determination. Time effect post feeding and hour/treatment interaction

Four five year-old, non-pregnant, non-lactating, cross goats (criolla $x$ Nubian) were used. They were fistulated with permanent cannulas for small ruminants.

The ruminal fluid was taken out through cannula at 0 , 2, 4, 6, 8 and $12 \mathrm{~h}$ after feed, and a digital $\mathrm{pH}$ meter (Silver Cap pH 5045-3B), equipped with a puncture electrode, and calibrated with buffer solutions to $\mathrm{pH}$ 4 and 7, was used. The area under the curve was calculated as the sum of the absolute value of the $\mathrm{pH}$ deviations below 5.8 and 6 values, registered as $\mathrm{pH} \mathrm{x}$ hour/day (Pitt y Pell, 1997). The mean value of ruminal $\mathrm{pH}$ and the time in hours with $\mathrm{pH}$ below 6 were determined. The effect of post-feed time and the time/treatment interaction were determined using a repeated measurements model (Littell et al., 1998).

\section{Experimental design and statistical analysis:}

Data were analyzed by the MIXED procedure (SAS, 2004) for a crossover design using a mixed model that included the fixed effect of sampling (treatment, period) and the random effect of the animal. Significant differences were considered with a $\mathrm{P}$ value $<0.05$ and tendencies $0.05>\mathrm{P}<0.10$.

\section{RESULTS AND DISCUSSION}

There were no significant effects $(p>0.05)$ on the total intake of dry matter (TDMI) -alfalfa hay, corn grain-, goat BW, and total digestibility of dry matter (TDMD) (table 2). The intake of energy concentrate recorded during the 8 hours after feeding showed a treatment effect with regard to time, verified by the hour/treatment interaction $(\mathrm{p}<0.05)$ (table 3; figure 1). As regards ruminal $\mathrm{pH}$, the areas under the curve with a $\mathrm{pH}$ threshold of 5.8 and 6 verified a significant linear decrease $(\mathrm{p}<0.05)$ for the D1 treatment. The treatment without monensin showed a tendency ( $\mathrm{p}=$ 0.074 ) to a greater number of hours with $\mathrm{pH}$ below 5.8 and the average $\mathrm{pH}$ of the day showed a tendency to be higher $(\mathrm{p}=0.056)$ for the D1 treatment (table 4 ). The minimum ruminal $\mathrm{pH}$ was observed between the 8 and 12 hours after food intake (figure 2), with significant differences $(p>0.05)$ between hours, and without treatment effects in the evolution of $\mathrm{pH}$ over time, evidenced in lack of interaction $(p>0.05)$ 
(table 5).

According to Elías (1983), Ramos (2005), Milleo et al., (2006), Arias et al., (2013) the incorporation of energy concentrates in diets for goats produces a decrease in ruminal $\mathrm{pH}$. Probably, as explained by Gonçalves (2001), ground cereal grains might cause insufficient salivary secretion at the ruminal level in order to maintain $\mathrm{pH}$ values between 6 and 7 . According to Pordomingo et al., (1999); Raun et al., (1976) and Dinius et al., (1976) the addition of $33 \mathrm{mg}$ of monensin/ $\mathrm{kg}$ of DM consumed avoids overconsumption. In this study, results demonstrate an increase in the number of daily concentrate meals in the treatment including the ionophore (Erickson et al., 2003). As regards intake regulation there are controversies among authors. In this sense, we disagree with Bergen \& Bates (1984), SchwartzkopfGenswein et al., (2003), Forbes, (2003), in that the use of monensin contributes to a decrease in the total intake, as demonstrated in this study. In relation to intake regulation, there are controversies among different authors as well. This study has shown that the use of monesine does not involve a decrease in the client's total intake therefore; we disagree with Bergen \& Bates (1984), Schwartzkopf-Genswein et al., (2003), and Forbes, (2003). According to Baran \& Žitñan (2002), Mouro et al., (2006), whose studies include sheep, the use of ionophores caused no alterations in dry matter intake compared to control treatments. In relation to ruminal $\mathrm{pH}$, the dose of monensin used in this investigation can be related to a decrease in hours with $\mathrm{pH}$ below 6 (Dennis et al., 1981).

Finally, it is worth mentioning that monensin showed no improvements on the total digestibility of the diet consumed (Mazza et al., 2001; Plata et al., 2004; Araújo et al., 2006).

\section{CONCLUSIONS}

The use of an ionophore such as monensin in goat diets with high concentration of starch had a moderating effect on the ruminal $\mathrm{pH}$, and on the number of energy concentrate daily meals. Results also showed no acute ruminal acidosis in any of the treatments, which may be attributed to goat's high adaptability to a wide range of food conditions.

\section{REFERENCES}

1. Araújo J.S., J.R.O. Pérez, P.C.A. Paiva, E.C.T.M. Peixoto, G.C. Braga, V. Oliveira \& L.C.D. Valle. 2006. Efeito da monensina sódica no consumo de alimentos e $\mathrm{pH}$ ruminalem ovinos. ArchVetSci11:39-43.

2. Arias, R., M. G. Muro, C.A. Cordiviola, M.S. Trigo, M. Brusa\& R. A. Lacchini. 2013. Incidencia de la proporción de maíz sobre la degradabilidad in situ de heno de alfalfa en dietas para caprinos. Revista de la Facultad de Agronomía, La Plata. 112 (2) 62-67.

3. Baran M \& R. Žitñan. 2002. Effect of monensin sodium on fermentation efficiency in sheep rumen. Arch TierzDummerstort45:181-185.

4. Bergen, W.G \& D.B. Bates. 1984. Ionophores: their effect on production, efficiency and mode of action. J. Anim. Sci. 58: 1465-1883.

5. Church, D.C. 1988. The ruminant animal. Digestive physiology and nutrition. Prentice Hall, Englewoods Cliffs, NJ. 641pp.

6. Dennis, S.M., T.G Nagaraja\& E.E Bartley. 1981 Effects of lasalocid or monensin on lactate-producing or-using rumen bacteria. J. Anim. Sci. 52: 418-426.

7. Dinius, D. A., M. S. Simpson and P. B. Marsh. 1976. Effect of monensin fed with forage on digestion and the ruminal ecosystem of steers. J. Anim. Sci. 42:229-234.

8. Duff, G. C., M. L. Galyean, M. E. Branine, D. M. Hallford, M. E. Hubbert, E. Fredrickson \& A. J. Pordomingo. 1990. Effects of continuous versus daily rotational feeding of monensin plus tylosin and lasalocid on serum insulin and growth hormone concentrations in beef steers fed a $90 \%$ concentrate diet. Proc. Natl. Amer. Soc. Anim. Sci. 41:55-58

9. Erickson, G. E., C. T. Milton, K. C. Fanning, R. J. Cooper, R. S. Swingle., J. C. Parrott, G. Vogel \& T. J. Klopfenstein. 2003. Interaction between bunk management and monensin concentration on finishing performance, feeding behavior, and ruminal metabolism during an acidosis challenge with feedlot cattle. J. Anim. Sci. 81:2869-2879.

10. Forbes, J. M. 2003. The multifactorial nature of food intake control. J. Anim. Sci. 81(E. Suppl. 2):E139-E144.

11. Gonçalves, A., R. Paula Lana, M. Teixeira Rodríguez, R. Mendonça Vieira, A. Queiroz\& D.Sampaio Henrique.2001. PadrãoNictemeral do pH Ruminal e Comportamento Alimentar de Cabras Leiteiras Alimentadas com Dietas Contendo Diferentes RelaçõesVolumoso: Concentrado. Rev. Bras. Zootec. 30(6):1886-1892.

12. Harwood, D. 2004. Diseases of dairy goats. In Practice 26 , pp. 248-259.

13. Littell, R. C., P. R. Henry \& C. B. Ammerman. 1998 Statistical analysis of repeated measures data using SAS procedures. J. Anim. Sci. 76:1216-1231.

14. Mazza, P.H., W.R. Soares, L. Melotti\& R. Manzini. 2001 Monensina e digestibilidad aparente em ovinos alimentados comproporções de volumoso/concentrado. ScientiaAgrícola58, 449-455.

15. Milleo, T.C., W. Hartman, J.A.G. Hill, U.G. Netto\& F.R Maurer Jr. 2006. Alteracoesclinicas e laboratoriaisem bovinos emquadro de acidose latica ruminal. Em: Anais.Seminario de IniciacaoCientifica da UniversidadeTuiuti do Parana, Curitiba. Pp 5.

16. Moore, J.A., M.H.Poore, J.M.Luginbuhl. 2002. By-product feeds for meat goats: Effects on digestibility, ruminal environment, and carcass characteristics. J. Anim. Science.80:1752-1758.

17. Mouro G.F., A.F Branco, D.L. Harmon, F.J. Maia, S.M Coneglian\& T.F. Minela. 2006. Fontes de carboidratos e ionóforoem dietas contendo óleo vegetal para ovinos: digestibilidade, balanço de nitrogênio e fluxo portal de nutrientes. R Bras Zootec35: 2144-2153.

18. Pitt, R. E. \& A. N. Pell. 1997. Modeling ruminal pH fluctuations: Interactions between meal frequency and digestion rate. J. DairySci. 80:2429-2441.

19. Plata F.X., R.R. Velasco, L.M. Melgoza, B.A. Lara, E. Aranda \& D. Mendoza. 2004. Un cultivo de levadura (Saccharomycescerevisiae) y la monensina sódica en el comportamiento productivo de ovinos, $R C$ 14: 522-525.

20. Pordomingo, A.J. 1990.Effects of daily and weekly rotations of lasalocid and monensin plus tylosin compared with continuous feeding of ionophores on ruminal fermentation in beef steers fed a $90 \%$ concentrate diet. PhD Dissertation, New Mexico State Univ. USA. pp.1-12.

21. Pordomingo, A.J., Galyean, M. E., Branine, M. E. \& Freeman, A.S. 1999.Effects of daily and weekly rotations of lasalocid and monensin plus tylosin compared with continuous feeding of each ionophore on daily dry matter intake and digest kinetics. Rev. Arg. Prod. Anim. 19:383 390.

22. Ramos, J. 2005. Obtención de un concentrado energético proteínico por fermentación en estado sólido de la caña de 
azúcar para bovinos en ceba. Dr. Tesis. Instituto de Ciencia Animal. La Habana, Cuba.

23. RasoolSadjadian, Hesam A. Seifi, MehrdadMohri, Abbas AliNaserian and NimaFarzaneh. 2013. Effects of Monensin on Metabolism and Production in Dairy Saanen Goats in Periparturient Period. Asian-Aust. J. Anim. Sci. 26:82-89

24. Santini, F.J. \& O.N. Di Marco. 1983. Monensina. Modo de acción y su efecto sobre el comportamiento productivo del animal. Rev. Arg. Prod. Anim. 3:345-
25. SAS institute inc.2004 SAS On line Doc\#9.1.3.cary, NC: SAS institute.inc.

26. Schwartzkopf-Genswein, K. S., K. A. Beauchemin, D. J. Gibb, D. H. Crews, Jr., D. D. Hickman, M. Streeter \& T. A McAllister. 2003. Effect of bunk management on feeding behavior, ruminal acidosis and performance of feedlot cattle: A review. J. Anim. Sci. 81:E149-E158.

\section{TABLES AND FIGURES}

Table1. Food chemical composition $(*)$

\begin{tabular}{|c|c|c|}
\hline Item & Alfalfa hay & Corn \\
\hline DM (\%) & 87.0 & 89.0 \\
\hline OM (\%) & 91.9 & 98.7 \\
\hline CP $(\%)$ & 13.7 & 7.3 \\
\hline CF (\%) & 24.9 & 2.1 \\
\hline EE $(\%)$ & 2,4 & 3,9 \\
\hline ENF (\%) & 37.3 & 72.8 \\
\hline NDF (\%) & 58.87 & 14.55 \\
\hline $\operatorname{ADF}(\%)$ & 44.03 & 3.68 \\
\hline TDN (\%) & 50.0 & 83.0 \\
\hline
\end{tabular}

(*) Animal Nutrition Laboratory of the School of Veterinary Sciences. UNLP.

DM: dry matter.

OM: organic matter.

CP: crude protein.

$\mathrm{CF}$ : crude fiber.

EE: ether extract.

ENF: extractive nitrogen-free.

NDF: neutral detergent fiber.

ADF: acid detergent fiber.

TDN: total digestible nutrients. 
Table 2. Linear effect and average comparison analysis of DMI, DMIF, DMIC and BW, according toeach treatment.

\begin{tabular}{lcccc}
\hline \multicolumn{1}{c}{ Item } & Diets & & SE & P values \\
\hline DMI (\% BW) & $\mathbf{D}_{\mathbf{0}}$ & $\mathbf{D}_{1}$ & & $\mathbf{L}$ \\
DMIah (g/d) & $2.80^{\mathrm{a}}$ & $2.81^{\mathrm{a}}$ & 0.173 & 0.951 \\
DMIc (g/d) & $387.78^{\mathrm{a}}$ & $426.58^{\mathrm{a}}$ & 34.42 & 0.425 \\
BW & $800.78^{\mathrm{a}}$ & $798.44^{\mathrm{a}}$ & 47.96 & 0.972 \\
TDMD (\%) & $43.75^{\mathrm{a}}$ & $43^{\mathrm{a}}$ & 2.43 & 0.833 \\
\hline
\end{tabular}

$\mathrm{D}_{0}$ : withoutmonensin.

$\mathrm{D}_{1}$ : withmonensin.

DMI (BW \%): dry matter intake relative to BW.

DMIah: dry matter intake alfalfa hay gr/day.

DMIc: dry matter intake corn gr/day.

BW: live weight.

TDMD: total dry matter digestibility.

SE: standard error.

L: Probability value associated with a linear effect.

$P$ values: The $p$ values of the effects of monensin.

Equal letters indicate non-significant differences for the $5 \%$ probability.

Table 3.Effect of time on corn intake during $8 \mathrm{~h}$ after feeding in a model of units repeated over time.

\begin{tabular}{lllllll}
\hline \multicolumn{1}{c}{ Item } & & & & & & SE \\
\hline Hours & 0 & 2 & 4 & 6 & 8 & \\
$\mathbf{N}^{\mathbf{0}}$ goats & 4 & 4 & 4 & 4 & 4 & \\
DMIc $^{\mathbf{1}}$ & $0^{\mathrm{a}}$ & $262^{\mathrm{b}}$ & $473^{\mathrm{c}}$ & $673^{\mathrm{d}}$ & $798^{\mathrm{d}}$ & 19.57
\end{tabular}

DMIc: dry matter intake corn for $8 \mathrm{~h}$.

$1=$ effect of hours on corn intake $(p<0.001)$.

SE: standard error.

Equal letters indicate non-significant differences for the $5 \%$ probability.

Figure 1: Analysis of feeder during 8 hours after concentrate was provided. Effect of treatment $(p=0.003)$. Interaction hour $*$ treatment $(\mathrm{p}<0.001)$.

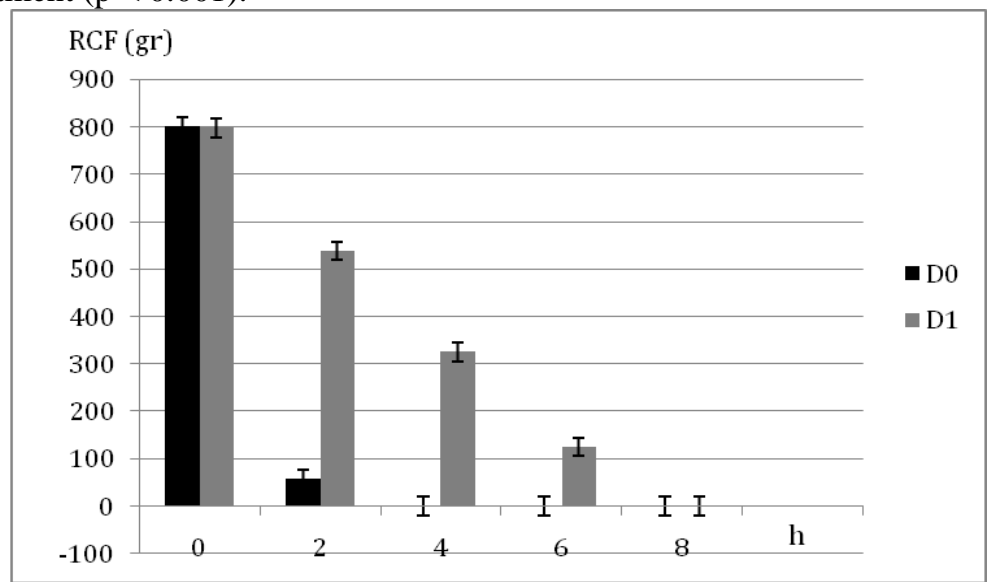

RCF: remnant corn in feeder.

D0: without monensin.

D1: with monensin. 
Table 4. Effect of monensin on ruminal $\mathrm{pH}$.

\begin{tabular}{|c|c|c|c|c|}
\hline \multirow{2}{*}{ Item } & \multicolumn{2}{|r|}{ Diets } & \multirow{2}{*}{ SE } & \multirow{2}{*}{$\frac{\text { Contrast }}{\mathrm{L}}$} \\
\hline & D0 & D1 & & \\
\hline $\mathrm{pH}<5.8 \mathrm{~h} / \mathrm{d}$ & $1.58^{\mathrm{a}}$ & $0.12^{\mathrm{b}}$ & 0.326 & 0.019 \\
\hline $\mathrm{pH}<6 \mathrm{~h} / \mathrm{d}$ & $2.73^{\mathrm{a}}$ & $0.94^{\mathrm{b}}$ & 0.513 & 0.049 \\
\hline AveragepH & $6.01^{\mathrm{a}}$ & $6.34^{\mathrm{a}}$ & 0.102 & 0.058 \\
\hline $\mathrm{H} \mathrm{pH}<6$ & $6.5^{\mathrm{a}}$ & $5^{\mathrm{a}}$ & 1.233 & 0.423 \\
\hline $\mathrm{H} \mathrm{pH}<5.8$ & 4 & 1.5 & 0.820 & 0.075 \\
\hline
\end{tabular}

D0: without monensin.

D1: with monensin.

$\mathrm{pH}<5.8(\mathrm{~h} / \mathrm{d}): \mathrm{pH}$ expressed as area under the curve of a $\mathrm{pH}$ threshold of 5.8.

$\mathrm{pH}<6(\mathrm{~h} / \mathrm{d}): \mathrm{pH}$ expressed as area under the curve of a $\mathrm{pH}$ threshold of 6 .

$\mathrm{pH}$ Prom:average $\mathrm{pH}$ day.

$\mathrm{Hr} \mathrm{pH}<6$ : hours with $\mathrm{pH}$ below 6 .

$\mathrm{Hr} \mathrm{pH}<5.8$ : hours with $\mathrm{pH}$ below 5.8 .

SE: standard error.

L: Probability value associated with a linear effect.

$P$ values: The $p$ values of the effects of monensin.

Equal letters indicate non-significant differences for the $5 \%$ probability.

Table 5. Effect of time on ruminal $\mathrm{pH}$ during 12 hours.

\begin{tabular}{|c|c|c|c|c|c|c|c|}
\hline Item & & & & & & & SE \\
\hline Hours & 0 & 2 & 4 & 6 & 8 & 12 & \\
\hline$N^{o}$ goats & 4 & 4 & 4 & 4 & 4 & 4 & \\
\hline $\mathbf{p H}^{1}$ & $7^{\mathrm{a}}$ & $6.53^{\mathrm{b}}$ & $6.03^{c}$ & $5.92^{\mathrm{cd}}$ & $5.79^{\mathrm{cd}}$ & $5.79^{d}$ & 0.053 \\
\hline
\end{tabular}

$\mathrm{pH}$ : pH ruminal.

$1=$ effect of hours on ruminal $\mathrm{pH}(\mathrm{p}<0.001)$.

SE: standard error

Equal letters indicate non-significant differences for the $5 \%$ probability.

Figure 2. $\mathrm{pH}$ variation during 12 hours. Treatment effect $(\mathrm{p}=0.005)$. Interaction hour $*$ treatment $(\mathrm{p}=0.354)$.

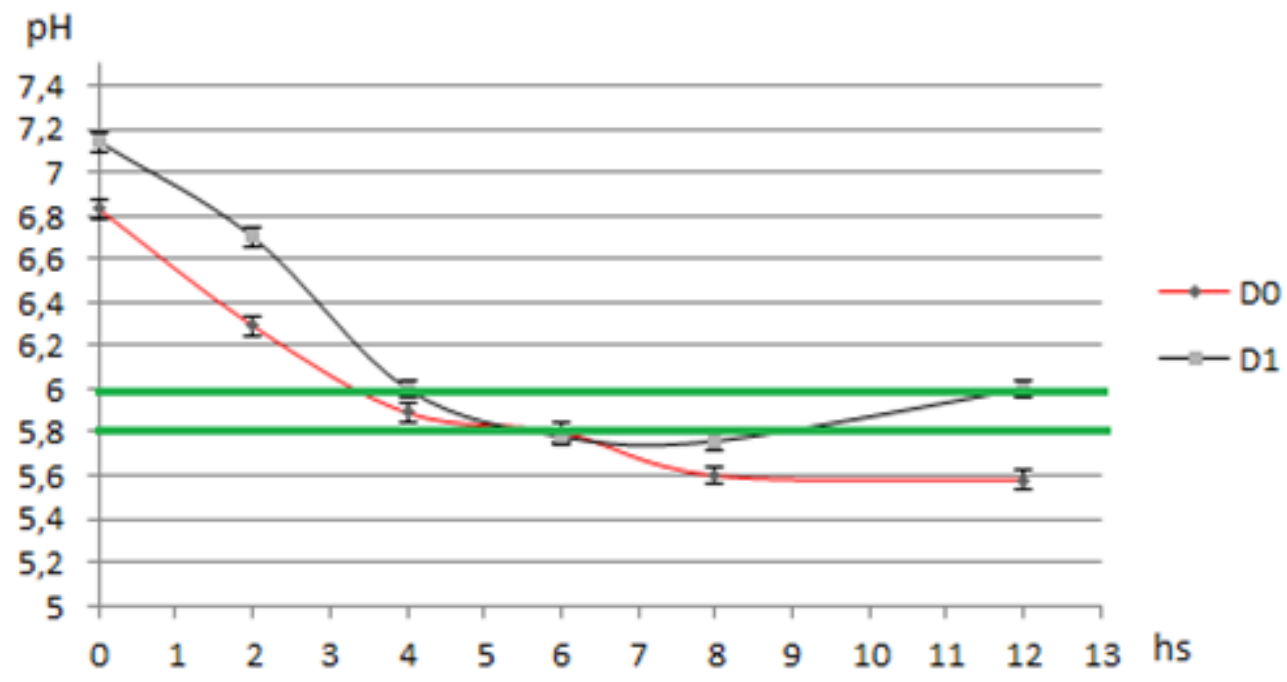

D0: without monensin.

D1: with monensin. 